\title{
Entrevista
}

\section{Laboratório de Estudos em Aquisição da Linguagem (LEAL)}

Elaine Grolla ${ }^{1}$

Universidade de São Paulo

\section{Entrevista concedida aos professores Kátia Abreu e Eduardo Kenedy}

Soletras: Quando o seu LAB foi fundado? Qual foi sua experiência em LABs de Psicolinguística anterior à fundação do LAB que coordena?

Eu já realizava pesquisas utilizando métodos experimentais desde o doutorado (defendido em 2005). Vim para a USP em 2006 (como pesquisadora de pós-doc) e continuei esse trabalho, mas sem ter um laboratório estruturado. Em 2010, após estar há dois anos conduzindo uma pesquisa financiada pela FAPESP (na modalidade Jovens Pesquisadores em Centros Emergentes, com cronograma de 4 anos), eu já tinha materiais e equipamentos necessários para a condução das pesquisas. Foi então em 2012, com meu início como orientadora no Programa de Pós-graduação do Departamento de Linguística da FFLCH/USP, que fundei o Laboratório de Estudos em Aquisição de Linguagem - o LEAL.

Minha experiência anterior foi no laboratório de aquisição do Departamento de Linguística da University of Connecticut, onde defendi meu doutorado. Lá, pesquisas sobre aquisição de inglês e da língua de sinais americana são conduzidas. Aprendi a aplicar experimentos e lidar com os dados trabalhando como RA (Research Assistant) da Professora Doutora Diane Lillo-Martin.

Soletras: Quais os principais temas de pesquisa que seu LAB vem contemplando ao longo dos anos?

Quando voltei para o Brasil, continuei com o tema de minha tese de doutorado, aquisição de pronomes e anáforas e a teoria de ligação. As primeiras dissertações de mestrado defendidas no LEAL também eram sobre ligação e aquisição de expressões anafóricas. Mais

\footnotetext{
${ }^{1}$ Professora doutora do Departamento de Linguística da USP. egrolla@ gmail.com 
recentemente, tenho trabalhado com aquisição de perguntas-QU e sua relação com o amadurecimento das funções executivas. Os trabalhos realizados no LEAL sob minha orientação são sobre temas variados, como aquisição de orações relativas, de morfologia verbal, de nomes nus singulares, de perguntas com QU in situ, de estruturas absolutas e de implicaturas escalares.

Soletras: Quais as principais técnicas experimentais que vêm sendo empregadas pesquisas de seu Lab nos últimos anos?

A maioria das pesquisas realizadas no LEAL trabalha com a tarefa de julgamento de valor de verdade (TJVV) e a tarefa de produção eliciada.

A TJVV é uma tarefa de compreensão, em que se apresenta uma história para criança, que fornecerá um contexto. Após a apresentação da história, uma sentença é pronunciada por um fantoche. A sentença proferida possui potencialmente duas interpretações, uma que respeita o princípio sob investigação e uma que viola tal princípio. Cada interpretação é associada a um valor de verdade (V e F). A tarefa da criança é julgar a sentença como verdadeira ou falsa, dado o contexto da história. A resposta da criança evidencia a interpretação que ela deu à sentença ambígua e, consequentemente, se ela respeita ou não o princípio investigado. Esse método é bastante eficiente, pois a tarefa da criança é bastante simples e podem ser testadas sentenças complexas, difíceis de serem encontradas na fala espontânea das crianças.

Já a tarefa de produção eliciada fornece um contexto apropriado para a produção de sentenças pela criança. Pode-se, por exemplo, pedir para a criança fazer perguntas a um fantoche ou pedir para ela que escolha entre duas figuras, o que ela fará por meio da produção de sentenças descrevendo a figura escolhida.

A escolha do método a ser empregado não é óbvia e depende do fenômeno estudado.

Soletras: Você poderia fazer uma estimativa do total de pesquisas de mestrado e doutorado que foram conduzidas no Lab?

Foram seis mestrados defendidos desde 2012. Oriento uma pesquisa de doutorado (em andamento, com previsão de defesa para 2019), além de três pesquisas de mestrado em andamento. 
Soletras: O Lab integra alguma rede de cooperação? Poderia citar outros Labs parceiros?

Não há cooperação com outros labs.

Soletras: Além de trabalhos teóricos de interesse para a área da Psicolinguística, seu Lab desenvolve também pesquisas de interface com a área da Saúde elou da Educação? Se sim, quais?

Não diretamente. Tivemos apenas uma pesquisa de mestrado desenvolvida com crianças portadoras de DEL (distúrbio específico de linguagem) em uma parceria com a fonoaudiologia da USP.

Soletras: Deixe uma palavra de seu Lab para os leitores alunos de graduação interessados em ingressar na área da psicolinguística experimental.

As línguas humanas são sistemas com propriedades extremamente complexas e abstratas. Estudos nas mais diversas línguas apontam para esse fato e nos fazem questionar como as crianças são capazes de, aos 3 anos de idade, entender e produzir um grande número de sentenças da língua que estão adquirindo. Aos 5 anos de idade, quase toda a estrutura de uma língua já foi adquirida. Esse feito é realizado por todas as crianças de desenvolvimento típico no mundo todo, sem esforço e sem ensinamento explícito. A pergunta que pesquisadores em aquisição de linguagem se colocam é: como isso é possível? No Laboratório de Estudos em Aquisição de Linguagem, são conduzidas pesquisas sobre diferentes fenômenos linguísticos, procurando por padrões e comportamentos que tragam mais indícios sobre como é o amadurecimento linguístico das crianças.

A área de aquisição de linguagem ainda é pouco difundida no Brasil e precisamos muito de pesquisadores interessados em investigar o desenvolvimento linguístico das crianças adquirindo Português Brasileiro. Muitos aspectos da aquisição da fonologia, sintaxe e semântica do PB ainda não foram explorados e é só com um número maior de alunos trabalhando em aquisição que conseguiremos chegar mais perto de uma resposta satisfatória para a pergunta feita acima. Então, se você se interessa pela área, considere-a seriamente. Realizar as pesquisas interagindo com crianças e/ou bebês é um trabalho extremamente recompensador!

Entrevista realizada em 14 de junho de 2017. 